\title{
HUBUNGAN KESESUAIAN SPESIFIKASI DEBIT AIR TABUNG UV-C DAN DEBIT OPERASIONAL DENGAN BAKTERI E.COLI PADA DEPOT AIR MINUM ISI ULANG DI WILAYAH KERJA PUSKESMAS II BATURRADEN KABUPATEN BANYUMAS TAHUN 2017
}

\author{
Rahmindy Dyar Augustin ${ }^{*}$, Sugeng Abdullah ${ }^{* *}$ ) \\ Jurusan Kesehatan Lingkungan, Politeknik Kesehatan Kemenkes Semarang, \\ Jl.Raya Baturaden KM 12 Purwokerto, Indonesia
}

\begin{abstract}
Abstrak
Depot Air Minum Isi Ulang (DAM) di Wilayah Kerja Puskesmas II Baturraden ada 8 DAM. Enam DAM (75\%) telah bersertifikat Laik Hygiene Sanitasi dari Dinas Kesehatan Kabupaten Banyumas, tetapi masih ditemukan E.coli pada air produknya. Keberadaan E.coli diduga adanya ketidaksesuaian antara spesifikasi debit air tabung UV-C dan debit operasional dengan bakteri E.coli. Jenis penelitian yang digunakan adalah penelitian analitik dengan tujuan untuk menganalisis kesesuian spesifikasi debit air tabung UV-C dan debit operasional dengan bakteri E.coli. Uji statistik yang digunakan Korelasi point Biserial. Hasil penelitian diperoleh DAM yang tidak memenuhi syarat secara biologis dua DAM (75\%) dan enam DAM (25\%) memenuhi syarat. Spesifikasi debit UV-C yang digunakan oleh DAM 2-5 GPM dan debit operasional yang dipakai berkisar 0,1-4,9 GPM. Tidak ada hubungan antara spesifikasi debit UV-C dan debit operasional pada Depot Air Minum Isi Ulang di Wilayah Kerja Puskesmas II Baturraden ( $p=$ 0,191). Tujuh DAM (87,5\%) DAM memiliki debit operasional sesuai dengan spesifikasi debit air UV-C. Akan tetapi, 25\% DAM positif E.coli pada air produknya. Disarankan seluruh DAM menggunakan spesifikasi debit air tabung UV-C sesuai standar yaitu 5 GPM (Galon Per Menit) dan perlu penelitian lebih lanjut dengan melibatkan sampel yang lebih banyak.
\end{abstract}

Kata kunci: debit UV-C, DAM, E.coli, kesehatan lingkungan

\begin{abstract}
The Correllation Discharge Specifications Of UV-C Tube Water And Operational Discharge With E.coli Bacteria At Drinking Water Refill Depot In Puskesmas II Baturraden Banyumas Disctrict Working Area In 2017. Drinking Water Refill Depot (DAM) in Puskesmas II Baturraden Banyumas District Working Area is eight. Six DAM's (75\%) have been health sertified from the Public Health Office of Banyumas District. However, E.Coli bacteria are still found in the water production. E.Coli languish allegedly because of the incongruity between $U V-C$ water tube discharge specifications and operational discharge with E.Coli bacteria. Statistic with Corelation Point Biserial. The research which is going to use is analytic research with analysing congeniality of UV-C water tube discharge specifications and operational discharge with E.Coli bacteria as the purpose. The research result showed that there are two DAMs which are not eligible biologically and six adequate DAMs. Discharge specifications of UV-C used by DAM 2-5 GPM and operational discharge used is ranged between 0,1 - 4,9 GPM. There is no correlation between discharge specification of UV-C and operational discharge at Drinking Water Refill Depot in Puskesmas II Baturraden Banyumas District Working Area $(p=0,191)$. Seven DAMs $(75 \%)$ has already been suitable with water discharge specification of UV-C. However,two DAMs (25\%) are positive E.Coli in the water production. It is suggested for all of DAM to use appropriate discharge specification of UV-C water tube of 5 GPM. Also, further research by involving more samples is suggested.
\end{abstract}

Keywords:author guidelines; journal; articletemplate;environmental health 


\section{Pendahuluan}

Depot Air Minum Isi Ulang (DAM) di Kabupaten Banyumas, Wilayah Baturraden meliputi 2 (dua) Wilayah Kerja Puskesmas, terdiri dari Wilayah Kerja Puskesmas I Baturraden jumlah 10 DAM, Wilayah Kerja Puskesmas II Baturraden jumlah 8 DAM. Wilayah Kerja Puskesmas II Baturraden merupakan kecamatan daerah wisata, sehingga masyarakat mempunyai inisiatif membuka usaha pengolahan air yakni Depot Air Minum Isi Ulang. Jumlah total DAM di Wilayah Kerja Puskesmas II Baturraden adalah 8 DAM. Total 8 DAM yang ada, 6 telah bersertifikat laik hygiene sanitasi dari Dinas Kesehatan Kabupaten Banyumas, setiap bulannya dilakukan pemeriksaan dan hasilnya memenuhi syarat dari segi uji bakteoriologis, serta 2 diantaranya belum memiliki ijin untuk melakukan usaha dan sampai saat ini belum pernah dilakukan pemeriksaan mikroba dari pihak Puskesmas.

Terdapat lima DAM di Kecamatan Baturraden yang menjadi sampel penelitian. Sampel air bakunya bersumber dari PDAM. Hasil pemeriksaan laboratorium didapat tiga DAMIU yaitu B,C,D kualitas bakteriologisnya telah memenuhi syarat yaitu 0 per 100 $\mathrm{ml}$ sampel, dua DAM kualitas bakteriologisnya belum memenuhi syarat yaitu DAM A 23 per $100 \mathrm{ml}$ sampel dan DAM E 2 per $100 \mathrm{ml}$ sampel.

Faktor yang berhubungan dengan cemaran bakteri pada Pengolahan air Depot Air Minum Isi Ulang salah satu diantaranya adalah kondisi peralatan depot air minum isi ulang, pengoperasian dan pemeliharaan. Salah satu peralatan krusial yang dimaksud adalah Lampu UV-C.

Pengoperasian UV-C yang tidak sesuai antara kapasitas dan kecepatan air yang melewati penyinaran ultraviolet air terlalu cepat, maka bakterinya tidak mati. ( Khiki Punawati,dkk, 2014). Banyak faktor yang mempengaruhi daya kerja sinar ultraviolet pada pengolahan air minum, diantaranya kekeruhan, kapasitas air, waktu kontak, debit. Lalu, bagaimana hubungan kesesuaian spesifikasi debit air tabung UV-C dan debit operasional dengan bakteri E.coli pada DAM.

Tujuan riset ini adalah menganalisis kesesuaian spesifikasi debit air tabung UV-C dan debit operasional dengan bakteri E.coli pada depot air minum isi ulang di Wilayah Kerja Puskesmas II Baturraden Kabupaten Banyumas Tahun 2017.

\section{Bahan dan Metode}

Bahan yang digunakan adalah Brosur Spesifikasi UV-C. Spesifikasi UV-C adalah data yang menjelaskan tentang karakteristik atau keadaan rinci suatu alat dalam hal ini adalah lampu Ultraviolet C.

Brosur atau manual digunakan untuk membandingkan spesifikasi UV-C dengan debit

\footnotetext{
${ }^{\text {*E)} E-m a i l: ~ r a h m i n d y d y a r @ y a h o o . c o m ~}$

${ }^{* * *}$ E-mail: sugengzend@gmail.com
}

operasional yang dipakai. Debit operasional didapat dengan menghitung volume (V) 5 galonan (19L) dan mencatat waktu (t) yang dibutuhkan untuk mengisinya. Kemudian debit (Q) diperoleh dengan membagi antara volume dengan waktu (t). Kemudian dilihat kesesuaian spesifikasi debit UV-C dan debit operasional, yaitu kecocokan antara data debit yang tercantum di brosur UV-C dimaksud dengan kenyataan saat digunakan.

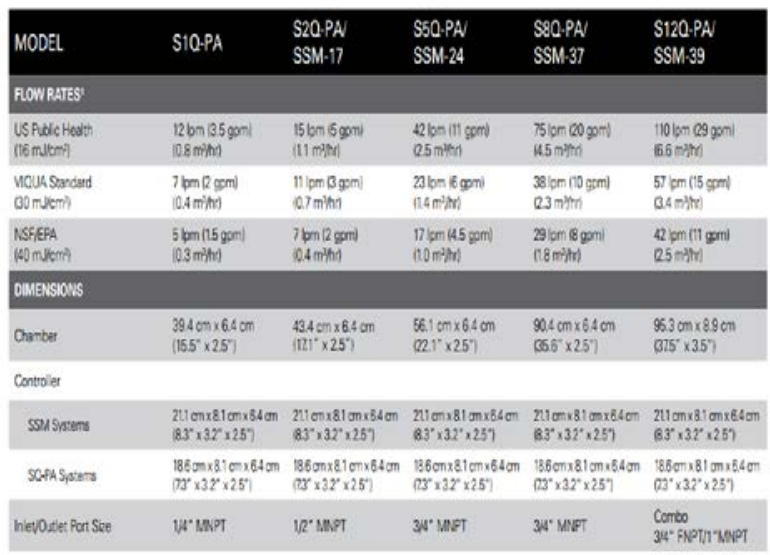

Gambar 1. Brosur Spesifikasi UV-C

Jenis Penelitian yang digunakan adalah penelitian observasional analitik dengan jenis penelitian analisis inferensial pendekatan cross sectional dengan uji statistik Korelasi Point Biserial. Populasi dan sampel dalam penelitian ini adalah seluruh Depot Air Minum Isi Ulang (DAM) yang ada di Wilayah Kerja Puskesmas II Baturraden yang berjumlah 8 DAM. Variabel bebas dalam artikel ini adalah kesesuaian spesifikasi air tabung UV-C dan debit operasional. Variabel terikat adalah bakteri E.coli. Pengumpulan data dilakukan dengan cara observasi yaitu dengan pengamatan secara langsung terhadap objek yang diteliti yaitu kondisi lingkungan sekitar DAM. Kemudian pengukuran debit air produk dan pengambilan sampel secara mikrobiologis yang dilakukan pihak Puskesmas II Baturraden bersamaan (segera) setelah atau sebelum pengukuran debit air produk oleh peneliti, hasil pemeriksaan menjadi data peneliti.

\section{Hasil dan Pembahasan}

a. Gambaran Umum Lokasi Penelitian

Kecamatan Baturraden merupakan salah satu Kecamatan yang berada di Kabupaten Banyumas, terletak $\pm 7 \mathrm{Km}$ arah kota Purwokerto (ibu kota Banyumas). Kecamatan dengan Luas Wilayah $\pm 45,53 \mathrm{Km} 2$, terdapat 12 desa yang terbagi menjadi dua Wilayah Kerja Puskesmas yaitu Puskesmas I Baturraden dan Puskesmas II Baturraden. Hampir seluruh penduduk yang ada di Kecamatan Baturraden memenuhi kebutuhan air minum dengan membeli Air Minum Isi Ulang di DAM terdekat. Depot Air Minum Isi Ulang di 
Wilayah Kerja Puskesmas II Baturraden mayoritas berada pada daerah yang strategis yaitu berada di pinggir Jalan Raya, sehingga memungkinkan masyarakat untuk dengan mudah membeli air minum isi ulang dan juga akses jalan yang mudah dijangkau serta adanya kebijakan pemilik DAM untuk menawarkan jasa mengantar pesanan air ke konsumen.

Pengamatan terhadap 8 DAM di Wilayah Kerja Puskesmas II Baturraden mayoritas memiliki kondisi Lingkungan yang cukup baik karena letaknya jauh dengan tempat pembuangan sampah. Akan tetapi, terdapat beberapa Depot Air Minum yang masih kurang baik apabila dilihat dari segi pemeliharaan lingkungan, seperti ditemukan adanya tumpukan kardus yang tidak dipakai, barang-barang bekas yang berserakan. Hal ini dapat menjadi tempat bersarangnya binatang pengganggu. Gambaran kondisi kerja alat desinfeksi. Rata-rata pemilik DAM menggunakan UV-C, tetapi masa kerja lampu dan panjang gelombang tidak diketahui dengan pasti. Hal ini karena tidak dilakukan pengukuran hanya berdasarkan nyala atau tidaknya lampu UV-C. Lampu merah dan hijau pada UV-C menjadi indikator. Pemilik DAM beranggapan meskipun masa kerja UV-C lebih dari 3 tahun asalkan saat tombol on ditekan lampu masih menyala masih dapat digunakan. Hampir seluruh DAM menggunakan UV-C yang memliki penetrasi $1,5 \mathrm{~cm}$ sampai $3,5 \mathrm{~cm}$.

b. Sumber Air Baku

Depot Air Minum Isi Ulang di Wilayah Kerja Puskesmas II Baturraden delapan buah. Seluruhnya dipilih sebagai tempat penelitian. Masing-masing DAM menggunakan air baku sebagaimana disajikan pada tabel 1 .

Tabel 1. Sumber Air Baku yang digunakan Depot Air Minum Isi Ulang di Wilayah Kerja Puskesmas II Baturraden Tahun 2017

\begin{tabular}{|c|c|c|c|c|}
\hline No & Nama DAM & Sumber Air Baku & $\begin{array}{l}\text { Kualitas } \\
\text { Fisik Air } \\
\text { Produk } \\
\text { (NTU) }\end{array}$ & $\begin{array}{c}\text { Kadar } \\
\text { maksimal } \\
\text { yang } \\
\text { diperboleh } \\
\text { kan } * \text { ) } \\
(\mathrm{NTU}) \\
\end{array}$ \\
\hline 1. & ARDEN & Sumur & 0,00 & 5 \\
\hline 2. & $\begin{array}{l}\text { PREMIUM } \\
\text { WATER }\end{array}$ & $\begin{array}{c}\text { Mata Air/PAM } \\
\text { Desa }\end{array}$ & 0,00 & 5 \\
\hline 3. & TUX & $\begin{array}{c}\text { Mata Air/PAM } \\
\text { Desa }\end{array}$ & 0,05 & 5 \\
\hline 4. & D \& D WATER & Mata Air & 0,00 & 5 \\
\hline 5. & RIZKA & Mata Air & 0,01 & 5 \\
\hline 6. & TIRTA WIJAYA & $\begin{array}{c}\text { Mata Air/PAM } \\
\text { Desa }\end{array}$ & 0,88 & 5 \\
\hline 7. & WATER ELEN & Mata Air & 0,5 & 5 \\
\hline 8. & KAMPUS 7 & Mata Air & 0,00 & 5 \\
\hline
\end{tabular}

Mata Air atau Pam Desa dan Sumur merupakan sumber air baku yang digunakan oleh Depot Air Minum Isi Ulang di Wilayah Kerja Puskesmas II Baturraden. Hasil pemeriksaan kualitas fisik di Laboratorium Masyarakat Banyumas seluruh DAM air produk DAM dalam kondisi yang jernih atau memenuhi syarat. 87,5\% DAM menggunakan Mata Air atau PAM Desa sebagai sumber air bersih, mengingat resiko kontaminasi E.coli lebih sedikit. Berdasarkan penelitian Anies dkk, (2015) sumber air baku mata air memiliki kualitas yang lebih baik bila dibandingkan dengan air baku sumur dan PDAM. Hal ini disebabkan karena mata air adalah air tanah yang keluar dengan sendirirnya. Mata air berasal dari tanah dalam, hampir tidak terpengaruh oleh musim dan bebas dari pencemar. Akan tetapi, jika terjadi kebocoran pada pipa dapat mengakibatkan pencemaran terhadap kualitas air, seperti DAM Water Elen. Sumber air baku berasal dari Mata Air, tetapi masih ditemukan E.coli pada air produk. Hal ini diduga karena air baku yang diambil dari mata air yang terbuka dan diindikasikan bahwa air telah terkontaminasi oleh tinja manusia.

Sumber air baku dikatakan baik apabila dapat dikonsumsi sebagai air minum dan mampu memenuhi kebutuhan sehari-hari. Pemenuhan kebutuhan sehari-hari diperlukan air yang memenuhi syarat kuantitas dan kualitas. Kualitas yang dimaksud memenuhi syarat fisik, biologi, kimia dan radioaktifitas.

c. Jenis Desinfeksi dan Kualitas Air Minum

Total Depot Air Minum Isi Ulang di Wilayah Kerja Puskesmas II Baturraden memilih UV-C sebagai alat desinfeksi dari pada yang lainnya. Berdasarkan hasil pemeriksaan kualitas bakteri E.coli pada air produk ditemukan dua DAM positif E.coli dan enam DAM negatif E.coli.

Penggunaan alat desinfeksi pada DAM didasarkan atas kebutuhan serta keinginan pengusaha. Beberapa macam proses desinfeksi yang ada pada dasarnya baik dalam menurunkan jumlah mikroba yang terkandung dalam air baku. Pengolahan air minum pada Depot Air Minum Isi Ulang di Wilayah kerja Puskesmas II Baturraden 100\% menggunakan UV-C.

Kualitas air minum berdasarkan parameter biologi pada air minum melalui proses pengolahan UV-C terdapat dua DAM yang tidak memenuhi syarat dan enam DAM memenuhi syara. Berikut tabel 2 akan disajikan jenis desinfeksi dan kualitas air minum isi ulang di Wilayah Kerja Puskesmas II Baturraden. 
Tabel 2. Jenis Desinfeksi dan Kualitas Air Minum Isi Ulang pada Depot Air Minum Isi Ulang Isi Ulang di Wilayah Kerja Puskesmas II Baturraden Tahun 2017

\begin{tabular}{|c|c|c|c|c|}
\hline \multirow[b]{2}{*}{ No } & \multirow[b]{2}{*}{ Nama DAM } & \multicolumn{2}{|c|}{$\begin{array}{c}\text { Jenis Desinfeksi } \\
\text { pada DAM }\end{array}$} & \multirow{2}{*}{$\begin{array}{c}\text { Kualitas } \\
\text { Bakteri } \\
\text { E.coli (per } \\
100 \mathrm{ml} \\
\text { sampel) }\end{array}$} \\
\hline & & $\begin{array}{l}\text { Sinar } \\
\text { UV-C }\end{array}$ & $\begin{array}{c}\text { Reserv } \\
e \\
\text { Osmosi } \\
(R O)\end{array}$ & \\
\hline 1. & ARDEN & $\sqrt{ }$ & - & 21 \\
\hline 2. & $\begin{array}{l}\text { PREMIUM } \\
\text { WATER }\end{array}$ & $\sqrt{ }$ & - & 0 \\
\hline 3. & TUX & $\sqrt{ }$ & - & 0 \\
\hline 4. & $\begin{array}{c}\text { D \& D } \\
\text { WATER }\end{array}$ & $\sqrt{ }$ & - & 0 \\
\hline 5. & RIZKA & $\sqrt{ }$ & - & 0 \\
\hline 6. & $\begin{array}{c}\text { TIRTA } \\
\text { WIJAYA }\end{array}$ & $\sqrt{ }$ & - & 0 \\
\hline 7. & $\begin{array}{l}\text { WATER } \\
\text { ELEN }\end{array}$ & $\sqrt{ }$ & - & 38 \\
\hline 8 & KAMPUS 7 & $\sqrt{ }$ & - & 0 \\
\hline
\end{tabular}

Depot Air Minum Isi Ulang yang positif E.coli dimungkinkan alat yang digunakan kurang bekerja optimal, disebabkan karena lampu UV sudah tidak dalam masa pakai. Umumnya, desinfeksi menggunakan UV-C hanya didasarkan atas menyala atau tidaknya lampu tanpa diketahui pasti panjang gelombang dari sinar UV-C. Faktor manusia seperti perilaku menyalakan lampu UV$\mathrm{C}$ hanya dilakukan saat ada pelanggan yang ingin membeli air minum. Setelah pengisisan selesai lampu kembali dimatikan dengan alasan hemat listrik. Hal ini bisa menjadi alasan ditemukannya E.coli pada air produk.

Berdasarkan penelitian Khiki Punawati dkk, (2014) hasil penelitian menunjukkan kondisi proses pengolahan telah memenuhi syarat. Akan tetapi, peralatan tertentu dalam proses pengolahan air tidak ada masa pemakaiannya sehingga akan mengurangi kinerja dari alat yang digunakan.

d. Debit

Depot Air Minum Isi Ulang di Wilayah Kerja Puskesmas II Baturraden proses desinfeksinya menggunakan UV-C. Beberapa spesifikasi terdapat pada alat, salah satunya spesifikasi debit air tabung UV-C. Spesifikasi debit UV-C yang dimaksud tertera pada brosur alat serta debit air operasional merupakan debit saat digunakan. Spesifikasi debit dan debit operasional pada Depot Air Minum Isi Ulang di Wilayah Kerja Puskesmas II Baturraden disajikan pada tabel 3.

Tabel 3. Debit Air Minum Isi Ulang pada Depot Air Minum Isi Ulang Isi Ulang di Wilayah Kerja Puskesmas II Baturraden Tahun 2017

\begin{tabular}{|c|c|c|c|c|c|}
\hline \multirow{2}{*}{ No } & \multirow{2}{*}{$\begin{array}{l}\text { Nama } \\
\text { DAM }\end{array}$} & \multirow{2}{*}{$\begin{array}{c}\text { Spesi } \\
\text { fikasi } \\
\text { Debit } \\
(\mathrm{GPM})\end{array}$} & \multicolumn{2}{|c|}{$\begin{array}{c}\text { Debit } \\
\text { Operasional }\end{array}$} & \multirow{2}{*}{$\begin{array}{c}\text { Kesesuaian } \\
\text { Spesifikasi } \\
\text { Debit dan } \\
\text { Debit } \\
\text { Operasional } \\
\end{array}$} \\
\hline & & & L/detik & $\begin{array}{c}\text { GP } \\
M\end{array}$ & \\
\hline 1. & ARDEN & 5 & 0,24 & $\begin{array}{c}3,7 \\
5\end{array}$ & Sesuai \\
\hline 2. & $\begin{array}{c}\text { PREMIU } \\
\text { M } \\
\text { WATER }\end{array}$ & 5 & 0,2 & $\begin{array}{c}3,1 \\
9\end{array}$ & Sesuai \\
\hline 3. & TUX & 3 & 0,14 & $\begin{array}{c}2,2 \\
3\end{array}$ & Sesuai \\
\hline 4. & $\begin{array}{c}\text { D \& D } \\
\text { WATER }\end{array}$ & 5 & 0,25 & $\begin{array}{c}3,8 \\
9\end{array}$ & Sesuai \\
\hline 5. & RIZKA & 3 & 0,29 & 4,6 & $\begin{array}{l}\text { Tidak } \\
\text { Sesuai }\end{array}$ \\
\hline 6. & $\begin{array}{c}\text { TIRTA } \\
\text { WIJAYA }\end{array}$ & 5 & 0,25 & $\begin{array}{c}3,8 \\
9\end{array}$ & Sesuai \\
\hline 7. & $\begin{array}{c}\text { WATER } \\
\text { ELEN }\end{array}$ & 2 & 0,09 & $\begin{array}{c}1,3 \\
8\end{array}$ & Sesuai \\
\hline 8. & $\begin{array}{c}\text { KAMPU } \\
\text { S } 7\end{array}$ & 1 & 0,027 & $\begin{array}{c}0,4 \\
2\end{array}$ & Sesuai \\
\hline
\end{tabular}

Beberapa spesifikasi terdapat pada alat UV-C, salah satunya spesifikasi debit air tabung UV-C. . Mengacu pada tabel 1 spesifikasi debit air tabung UV-C pada Depot Air Minum Isi Ulang di Wilayah Kerja Puskesmas II Baturraden di peroleh dari brosur di internet yang dianalogikan sesuai dengan debit pada alat yang dipakai, sedangkan debit operasional merupakan debit saat digunakan, didapat dengan menghitung volume dan waktu kontak. Volume pada seluruh DAM sama yaitu $19 \mathrm{~L}$ atau5 botol galon, dan waktu kontak yang dimaksud adalah waktu yang dibutuhkan untuk mengisi satu galon penuh.

Urutan spesifikasi debit air tabung UVC yang dipakai oleh DAM di Wilayah Kerja Puskesmas II Baturraden adalah jenis 5 GPM, 3 GPM dan 2 GPM. Spesifikasi 5 GPM digunakan oleh DAM Arden, Premium Water, D\&D Water, dan Tirta Wijaya.

Seluruh DAM tersebut memiliki kesesuaian antara spesifikasi debit air tabung UV-C dan juga debit saat dioperasionalkan yaitu DAM Arden 3,75 GPM, DAM Premium Water 3,19 GPM, D\&D Water 3,89 GPM, dan Tirta Wijaya 3,89 GPM. Spesifikasi 3 GPM dipakai oleh DAM Tux dan DAM Rizka, dari dua DAM tersebut salah satu memiliki debit yang tidak sesuai antara spesifikasi debit pada alat UV-C dan debit saat digunakan yaitu DAM Rizka 4,6 GPM. 
Sebagian besar spesifikasi debit air tabung UV-C yang digunakan oleh DAM di Wilayah Kerja Puskesmas II Baturraden adalah 5 GPM. Alasan dipilih karena sesuai standar DAM yang ditetapkan oleh Asosiasi DAM.

\section{e. Jumlah Bakteri}

Hasil pemeriksaan pada Depot Air Minum Isi Ulang diperoleh DAM yang memenuhi syarat secara biologi enam sedangkan DAM yang tidak memenuhi syarat sebanyak dua yaitu DAM Arden dan DAM Water Elen dengan jumlah E.coli 21 per $100 \mathrm{ml}$ sampel dan 38 per $100 \mathrm{ml}$ sampel. Berikut ini akan disajikan kualitas bakteri E.coli pada tabel 4.

Tabel 4. Kualitas Bakteri E.coli DAM di Wilayah Kerja Puskesmas II Baturraden Tahun 2017

\begin{tabular}{|c|c|c|c|}
\hline No & $\begin{array}{l}\text { Nama } \\
\text { DAM }\end{array}$ & $\begin{array}{c}\text { Kualitas Bakteri } \\
\text { E.Coli (per } \\
100 \mathrm{ml} \\
\text { Coliform) } \\
\end{array}$ & $\begin{array}{l}\text { Kadar maksimal } \\
\text { mikroba yang } \\
\text { diperbolehkan*) }\end{array}$ \\
\hline 1. & ARDEN & 21 & 0 \\
\hline 2. & $\begin{array}{l}\text { PREMIUM } \\
\text { WATER }\end{array}$ & 0 & 0 \\
\hline 3. & TUX & 0 & 0 \\
\hline 4. & $\begin{array}{c}\text { D \& D } \\
\text { WATER }\end{array}$ & 0 & 0 \\
\hline 5. & RIZKA & 0 & 0 \\
\hline 6. & $\begin{array}{c}\text { TIRTA } \\
\text { WIJAYA }\end{array}$ & 0 & 0 \\
\hline 7. & $\begin{array}{l}\text { WATER } \\
\text { ELEN }\end{array}$ & 38 & 0 \\
\hline 8 & $\begin{array}{c}\text { KAMPUS } \\
7\end{array}$ & 0 & 0 \\
\hline
\end{tabular}

*Baku Mutu Permenkes RI No.492 Tahun 2010 tentang Kualitas Air Minum

Hasil pemeriksaan MPN E.coli pada DAM yaitu dua DAM (25\%) tidak memenuhi syarat dan enam DAM (75\%) memenuhi syarat, DAM yang tidak memenuhi syarat yaitu DAM Arden dengan kadar E.coli 21 per $100 \mathrm{ml}$ sampel dan DAM Water Elen 38 per $100 \mathrm{ml}$ sampel.

Berdasarkan hasil tersebut air minum isi ulang yang dikonsumsi oleh masyarakat di sekitar DAM Arden dan DAM Water Elen tercemar oleh bakteri E.coli. Hal ini dimungkinkan karena kurang optimalnya alat desinfeksi yang digunakan, faktor lain yang mendukung adalah salah satu dari DAM yang tidak memenuhi syarat tersebut belum bersertifikasi atau belum terdaftar izin beroperasi di Dinas Kesehatan Kabupaten Banyumas. Akibatnya, pengawasan terhadap kegiatan DAM belum maksimal dilakukan serta kurangnya kesadaran dari pemilik DAM untuk mendaftarkan depotnya di Dinas Kesehatan Kabupaten Banyumas.

Persyaratan bakteriologis berdasarkan jumlah E.coli dalam setiap $100 \mathrm{ml}$ air menurut Peraturan
Menteri Kesehatan RI No. 492 Tahun 2010 tentang Kualitas Air Minum, jumlah maksimum yang diperbolehkan 0 (nol) per $100 \mathrm{ml}$ sampel air minum.

f. Analisis Kesesuaian Spesifikasi Debit Air Tabung UV-C dan Debit Operasional dengan Bakteri E.coli

Kesesuaian spesifikasi debit air tabung UV-C dan debit operasional dengan pemenuhan kualitas bakteri E.coli pada Depot Air Minum Isi Ulang di Wilayah Kerja Puskesmas II Baturraden dapat dilihat pada tabel 5.

Tabel 5. Kesesuaian Debit dengan Pemenuhan Kualitas Bakteriologis E.coli

\begin{tabular}{|c|c|c|c|c|}
\hline \multirow[t]{2}{*}{ No } & \multirow[t]{2}{*}{ Nama DAM } & \multirow{2}{*}{$\begin{array}{l}\text { Kesesuaian } \\
\text { Spesifikasi } \\
\text { Debit }\end{array}$} & \multicolumn{2}{|c|}{$\begin{array}{c}\text { Pemenuhan } \\
\text { Kualitas bakteri } \\
\text { E.coli }\end{array}$} \\
\hline & & & $M P N$ & $\begin{array}{c}\text { MS/TM } \\
\mathrm{S}\end{array}$ \\
\hline 1. & ARDEN & Sesuai & 21 & TMS \\
\hline 2. & $\begin{array}{l}\text { PREMIUM } \\
\text { WATER }\end{array}$ & Sesuai & 0 & MS \\
\hline 3. & TUX & Sesuai & 0 & MS \\
\hline 4. & D \& D WATER & Sesuai & 0 & MS \\
\hline 5. & RIZKA & Tidak Sesuai & 0 & MS \\
\hline 6. & TIRTA WIJAYA & Sesuai & 0 & MS \\
\hline 7. & WATER ELEN & Sesuai & 38 & TMS \\
\hline 8. & KAMPUS 7 & Sesuai & 0 & MS \\
\hline
\end{tabular}

Mengacu pada teori apabila spesifikasi debit air tabung UV-C sudah sesuai maka seharusnya tidak ditemukan E.coli dalam air produk. Akan tetapi, hasil penelitian kali bertentangan dengan teori yakni DAM yang memiliki spesifikasi sesuai justru ditemukan E.coli, sedangkan salah satu DAM negatif E.coli mempunyai spesifikasi debit air tabung UV-C yang tidak sesuai dengan debit operasional. Faktor yang diduga menjadi penyebab adanya E.coli dalam air produk pada DAM Arden dan DAM Water Elen adalah kondisi peralatan DAM yang tidak bekerja maksimal serta pemeliharaan yang kurang. Selama operasional, efektifitas alat tidak diperhatikan oleh pemilik DAM.

DAM pertama yang positif E.coli adalah DAM Arden. DAM ini mulai beroperasi tahun 2013. Sejak awal beroperasi lampu mengalami pergantian selama 4 kali, terakhir diganti bulan Maret. Penelitian dilakukan pada bulan Februari. Maka dapat dipastikan saat pengambilan sampel lampu belum mengalami pergantian. Selain itu, berdasarkan observasi salah satu sisi lampu tidak menyala. Hal tersebut memperkuat bahwa kondisi kerja lampu tidak maksimal sehingga mengakibatkan adanya E.coli pada air produknya.

DAM kedua yakni DAM Water Elen. DAM ini beroperasi \pm 7 tahun yang lalu, sama halnya 
dengan Arden lampu UV-C juga baru diganti satu bulan yang lalu. Saat penelitian dilakukan lampu tidak menyala. Perawatan lampu jarang dilakukan. Hal ini terlihat dari kondisi UV-C yang sangat kotor. Tabung selongsong UV-C tidak pernah dibersihkan bahkan tidak akan disentuh selama lampu masih menyala dengan alasan karena hal ini hanya bisa dilakukan oleh tenaga khusus saja.

Sedangkan untuk DAM yang memiliki ketidaksesuaian antara spesifikasi debit air tabung UV-C dan debit operasional diduga kondisi kerja alat desinfeksi sudah bekerja dengan baik dan juga pemeliharaan alat sudah bagus. Bahkan DAM Rizka dimungkinkan memiliki kondisi air sudah baik sebelum melewati alat desinfeksi karena menggunakan alat filter yang sudah bagus.

Kondisi kerja peralatan dan juga pemeliharaan peralatan pengolahan air minum isi ulang dapat menjadi penyebab kontaminasi bakteri. Apabila penangan sarana kurang baik, maka dapat terkontaminasi mikroba patogen. Sehingga perlu upaya pembersihan terhadap instalasi pengolahan air minum secara berkala terutama alat desinfeksi untuk meningkatkan kualitas air yang dihasilkan. (Efri Malisa Dwi Putri, 2015).

\section{Kesimpulan}

Spesifikasi debit air tabung UV-C yang digunakan oleh Depot Air Minum Isi Ulang di Wilayah Kerja Puskesmas II Baturraden adalah 5 GPM (50\%), 3 GPM (37,5\%), dan 2 GPM (12,5\%).

Debit operasional yang dipakai oleh DAM di Wilayah Kerja Puskesmas II Baturraden berkisar 0,1-0,9 GPM (12,5\%), range 1-1,9 GPM (12,5\%), range 2-2,9 GPM (12,5\%), range 3-3,9 GPM (50\%) dan range 4-4,9 GPM (12,5\%).

Depot Air Minum Isi Ulang di Wilayah Kerja Puskesmas II Baturraden yang tidak memenuhi syarat secara biologis dua DAM (25\%) dan yang memenuhi syarat biologis enam DAM (75\%).

Tidak ada hubungan kesesuaian spesifikasi debit air tabung UV-C dan debit operasional dengan bakteri E.coli $(\mathrm{p}=0,191)$.

\section{Ucapan Terima Kasih:}

Ibu, bapak, serta teman-teman yang telah memberikan dukungan, semangat serta do'a yang terbaik.

\section{Daftar Pustaka}

Astuti, Sarwendah D, Suhartono, Suwondo, 2014, Faktor-faktor yang Berhubungan Dengan Angka Kuman dalam Air Produk Air Minum isi Ulang di Pemalang, Jurnal Kesehatan Lingkungan Indonesia, April 2014. Vol 13.

Chay Asdak, 2007, Hidrologi dan Pengelolaan DAS: GM University Press.
C. Totok Sutrisno, dkk, 2010, Tekhnologi Penyediaan Air Bersih, Jakarta: Rineka Cipta.

Dian Anggraini T, 2012, Aspek Kualitas Air dan Hygiene Sanitasi Depot Air Minum Isi Ulang (DAMIU) di Kecamatan Kota Utara Kota Gorontalo Tahun 2012, Skripsi: Jurusan Kesehatan Masyarakat Fakultas Ilmu-ilmu Kesehatan dan Keolahragaan Universitas Negeri Gorontalo.

Efri Malisa Dwi, 2015, Hubungan Higiene Sanitasi Dengan Kontaminasi Bakteri Colifrom pada Air Minum Isi Ulang di Kecamatan Seberang Ulu 1 Kota Palembang Tahun 2015, Skripsi, Universitas Islam Negeri Syarif Hidayatullah Jakarta.

Elyana Onna, 2012, Pengukuran Debit, at https://elyanaonna.wordpress.com/2014/04/13/pe ngukuran-debit-air/ Diakses 18 Januari 2017.

Gabriel, J.F, 2001, Fisika Lingkungan, Hipokrates.

Herwanti, 2013, Studi Kualitas Bakteriologis Depot Air Minum Isi Ulang (DAMIU) di Wilayah Kerja Puskesmas Purwokerto Selatan Kabupaten Banyumas Tahun 2013, KTI, Purwokerto: Kementerian Kesehatan RI Politeknik Kesehatan Kemenkes Kesehatan Semarang Jurusan Kesehatan Lingkungan Purwokerto

Kartika Widyasari, 2015, Cara Sederhana Mencegah Keberadaan Tikus di Rumah at http://etosonline.com/5-cara-cegah-tikus-berkeliaran-dirumah/

Kasim, Khiki Punawati, Onny Setiani, Nur Endah, 2014, Faktor-faktor yang Berhubungan dengan Cemaran Mikroba dalam Air Minum Isi Ulang pada Depot Air Minum Kota Makassar, Jurnal Kesehatan Lingkungan, Oktober 2014. Vol 13 No 12.

Sukmayati Alegantina, Anis Isnawati, 2008, Pengembangan Model Proses Filtrasi dan Desinfeksi yang Mempengaruhi Kualitas Air Minum, Media Litbang Kesehatan Volume VIII Nomor 3 tahun 2008.

Sulistyandari, H, 2009, Faktor-Faktor yang Berhubungan dengan Kontaminasi Deterjen pada Air Minum Isi Ulang di Depot Air Minum Isi Ulang (DAMIU) di Kabupaten Kendal Tahun 2009, Tesis Program Magister Kesehatan Lingkungan, Semarang: Universitas Diponegoro.

Suparmin, 2011, Teori dan Praktik Pengolahan Air Minum, Banyumas: Yayasan Sanitarian Banyumas.

Surya Andalas Putra, 2010, Analisis Kuantitatif Bakteri Coliform pada Depot Air minum Isi Ulang di Purwokerto Kabupaten Banyumas Tahun 2010, KTI, Purwokerto: Politeknik Kesehatan Kementrian Kesehatan Semarang Jurusan Kesehatan Lingkungan. 
Srikandi Fardiaz, 1992, Polusi Air dan Udara, PAU: Intstitut Pertanian Bogor, Yogyakarta: Kanisius.

Tri Cahyono, 2014, Pedoman Penulisan Proposal Penelitian dan Karya Tulis Ilmiah, Purwokerto Kementerian Kesehatan RI Akademi Kesehatan Lingkungan Purwokerto.

Undang-Undang Nomor 36 Tahun 2009 Tentang Kesehatan

at

http://sireka.pom.go.id/requirement/UU-36-2009Kesehatan.pdf Diakses 17 Februari 2017.

Wiyatri Sulharini, 2016, Kualitas Mikrobiologis Air Minum Isi Ulang Botol Berkran Yang Dijual pada Warung di Kecamatan Baturraden Tahun 2016, KTI, Purwokerto: Kementrian Kesehatan RI Politeknik Kesehatan Kementrian Kesehatan Semarang Jurusan Kesehatan Lingkungan. 